\title{
EMOTIONS VERSUS SELF-KNOWLEDGE IN JOSEPH CONRAD'S LORD JIM AND THE SHADOW-LINE
}

\author{
Agata Kowol \\ The Jagiellonian University, Kraków
}

\begin{abstract}
The aim of this paper is to examine the impact that emotions exert on the process of acquisition of self-knowledge in the case of the main protagonists of Joseph Conrad's Lord Jim and his The Shadow-Line. What is characteristic of both is that the continuity of their safe established lives is disrupted by their sudden and impulsive actions, which determine their fates and consciousnesses: Jim's fatal jump from the Patna, and a seemingly unmotivated resignation from a satisfactory job of the young Captain, respectively. Both actions seem to have been a result of the characters' excessive self-centredeness, their mood swings, overheated imagination, self-delusion and undervalued self-estimation, which are typical of youth, a period marked by disproportionate emotionality and a necessity to take decisions which will shape one's future life. In Conrad's world, pursuit of self-knowledge assumes the proportions of a moral imperative of every human being. The cases of Jim and the young Captain are considered against the backdrop of Conrad's epistemological scepticism and heroic ethics.
\end{abstract}

Keywords: Joseph Conrad, Lord Jim, The Shadow-Line, emotions, self-knowledge, self-delusion, imagination

\section{LORD JIM}

The aim of this paper is to examine the impact that emotions, imagination and excessive self-centredness exert on the self-knowledge of the main protagonists of two works by Joseph Conrad: Lord Jim and The Shadow-Line. What is characteristic of both figures is that their safe and established lives are disrupted by their sudden and impulsive actions, which determine their fates and define their consciousnesses, i.e., Jim's fatal jump from the Patna, and the seemingly unmotivated resignation from a satisfactory job by the young Captain, respectively. As stated by Tanner, "It is in these people that Conrad thought we could see the moral problems of the world working themselves out. For these men enter the moral universe" (1963: 58). Through their acts they embark on a journey into the depths of human nature, allowing the readers an insight into the complexity of human conduct and conscience. 
The eponymous protagonist of Lord Jim, affected by "light literature" (Conrad, 1996: 8) and a romantic turn of mind, dreams of performing heroic deeds, but at a critical moment deserts what he thinks is a sinking ship, full of Moslem pilgrims travelling to Mecca. However, the Patna does not sink, and his act of cowardice is brought to light and associated with his name thereon: "When the fact broke through the incognito he would leave suddenly the seaport where he happened to be at the time and go to another-generally further east. [...] He retreated in good order towards the rising sun, and the fact followed him casually but inevitably" (Conrad, 1996: 8). What Jim seems to fail to acknowledge, though, due to his excessive emotionality, is precisely "the fact." Although some critics claim that in the novel's plot both Jim, the protagonist, and Marlow, the internal narrator of the frame structure, undergo change (Stape, 1996: 66), and they call Lord Jim Conrad's "most sustained attempt to write a Bildungsroman" (Stape, 1996: 63), it is debatable to what extent in fact Jim experiences the process of education, as he seems to have failed to confront both the moral demands of adulthood and the consequences of and the truth about his shameful deed.

The first four chapters of the novel are narrated by an omniscient third-person authorial voice and introduce Jim's physical appearance, family background, early training career, and his "dogged self-assertion $[\ldots]$ directed $[\ldots]$ as much at himself as at anybody else" (Conrad, 1996: 7), but, most importantly, his constant day-dreaming:

He saw himself saving people from sinking ships, cutting away masts in a hurricane, swimming through a surf with a line; or, as a lonely castaway, barefooted and half-naked, walking on uncovered reefs in search of shell-fish to stave off starvation. He confronted savages on tropical shores, quelled mutinies on the high seas, and in a small boat upon the ocean kept up the hearts of despairing men-always an example of devotion to duty, and as unflinching as a hero in a book. (Conrad, 1996: 9)

Jim fails to see the actual reality because the only one he seems to recognise is that of his dreams. He successfully manages to intoxicate himself with illusions of his own superiority, his inclination to dreaming fuelled by "light literature."

In fact, Jim's self-mythologising could be perceived as a form of bovarism, but it may also be considered part of the $19^{\text {th }}$-century romantic tradition of the supreme value of self and the concept of a Romantic hero: "the great and lonely individual elevated above the common herd of society by the scope of his imagination, his dedication to dreams and Ideals, his contempt for the prosaic trivia of day-to-day existence" (Tanner, 1963: 7-8). According to Watt, "[o]ne of the residual legacies of the Romantic movement was a disheartened awareness of the discrepancy which the individual imagination is continually discovering between the self as it is and the self as it would like to be" (1980: 324). Tanner notes that Jim's story, just as the story of Don Quixote, tragically and ironically, "forces the heroic Ideals into damaging collision with unredeemed, earthy empirical reality" (1963: 8). Conrad returns to the theme in the figure of Stein later in the novel, while the "screen of heroic adventure, this special set of coloured glasses, continues right through the end of the novel, de- 
termining how Jim imagines he can use Patusan, Jewel, Brown, and determining to the end his conception of both heroism and redemption" (Johnson, 1985: 64).

Jim's psychological make-up presupposes the implications of his ignorance of, thoughtlessness about and indifference to the multifaceted nature of reality, ambiguities inherent in life, and his limited ability to act promptly and rightly when confronted with danger. These become manifest in the episode on the training ship, when Jim for the first time fails to act in an emergency and thus apparently misses a chance for a heroic deed while it is another man who plays the leading part in this little drama. What Jim also fails in is self-knowledge. At first he feels "the pain of conscious defeat" and envy of the hero of the day, but a moment later he knows "what to think of it" (Conrad, 1996: 10). He

thought it a pitiful display of vanity. The gale had ministered to a heroism as spurious as its own pretence of terror. He felt angry with the brutal tumult of earth and sky for taking him unawares and checking unfairly a generous readiness for narrow escapes. Otherwise he was rather glad he had not gone into the cutter, since a lower achievement had served the turn. He had enlarged his knowledge more than those who had done the work. When all men flinched, then-he felt sure-he alone would know how to deal with the spurious menace of wind and seas. He knew what to think of it. Seen dispassionately, it seemed contemptible. He could detect no trace of emotion in himself, and the final effect of a staggering event was that, unnoticed and apart from the noisy crowd of boys, he exulted with fresh certitude in his avidity for adventure, and in a sense of many-sided courage. (Conrad, 1996: 10-11)

The irony in the account of the narrator-observer, who at times (as here) seems to adopt Jim's perspective, only highlights the protagonist's inauspicious proneness to self-delusion: "Jim's habit of individualistic reverie ominously isolates him from his comrades. [...] Jim's imagination, ceasing to engage with reality, has started to spin freely. What he has done is to exchange his real self for an ideal self, and simultaneously to invent the mechanism required to safeguard it" (Berthoud, 1978: 72).

From the very beginning of the novel Jim appears to bear a grudge against the external world every time it catches him "unawares." Such is the case of his fatal jump from the Patna: "He had been taken unawares-and he whispered to himself a malediction upon the waters and the firmament, upon the ship, upon the men. Everything had betrayed him! He had been tricked into that sort of high-minded resignation which prevented him lifting as much as his little finger [...]" (Conrad, 1996: 60). When the unexpected does happen, he fails the test that life makes him face, and which seems a necessary step in his pursuit of self-knowledge. Instead of fully acknowledging his guilt in the Patna's accident, he keeps searching for extenuating circumstances and blames the external world, for instance, other people for it: "I jumped! I told you I jumped; but I tell you they were too much for any man. It was their doing as plainly as if they had reached up with a boat-hook and pulled me over. Can't you see it? You must see it. Come. Speak-straight out" (Conrad, 1996: 77). Moreover, he has a déjà $v u$ about having been fooled by fate: "the event that had stripped him of his honour was, all along, an opportunity for glory easy beyond his wildest dreams" (Berthoud, 1978: 76). 
Jim's self-preoccupation and self-idealisation appear to be associated with lack of self-knowledge, particularly, as regards his own weaknesses. Significantly, Marlow declares that "Jim had no dealings but with himself" (Conrad, 1996: 201). According to Watt, Jim's self-centredness "encourages a personal pride and self-sufficiency which leads the individual to put his primary trust in himself, instead of relying on divine grace, moral virtue, civic duty, or personal feeling" (1980: 353).

Another of Jim's important characteristics is his marked underestimation of work and duty. Rather than attain an "effacement of the self before the work at hand" (Stape, 1996: 70), which is most desirable in Conrad's opinion, as it allows one to curb excessive self-preoccupation and develop a sense meaningfulness of one's action, Jim projects a vision of himself "that lacks any basis in reality," which is the reason why he "finds the conditions of the world itself inadequate" (Stape, 1996: 70). This leads him to an utterly egotistic focus on himself, which, together with his overheated imagination, is "a mechanism that is capable of, even fundamentally oriented to, the engendering of mere illusion" (Stape, 1996: 71).

According to the external narrator, imagination may even be detrimental to one's alertness and ability to act, or react properly in an emergency: "[ $t$ ]he danger, when not seen, has the imperfect vagueness of human thought. The fear grows shadowy; and Imagination, the enemy of men, the father of all terrors, unstimulated, sinks to rest in the dullness of exhausted emotion" (Conrad, 1996: 11-12). Thus, at the moment of crisis on the Patna, instead of acting decisively, Jim loses possession of himself and finds himself paralysed. Paradoxically, it is not his cowardice that disables him, but his imagination, which "transforms possibility into accomplished fact" (Daleski, 1977: 93) and makes him surrender to despair. As Marlow diagnoses him:

He was not afraid-oh no! only he just couldn't—-that's all. He was not afraid of death perhaps, but I'll tell you what, he was afraid of the emergency. His confounded imagination had evoked for him all the horrors of panic, the trampling rush, the pitiful screams, boats swamped-all the appalling incidents of a disaster at sea he had ever heard of. He might have been resigned to die but I suspect he wanted to die without added terrors, quietly, in a sort of peaceful trance. (Conrad, 1996: 56)

Jim himself does not understand his own self, therefore, his efforts to make others understand him seem doomed to failure, the more so that he can never communicate with them and he finds himself completely isolated. Marlow's efforts to understand the young officer are hindered by Jim's self-delusions and self-preoccupation: "He would be confident and depressed all in the same breath, as if some conviction of innate blamelessness had checked the truth writhing within him at every turn" (Conrad, 1996: 51). In addition, Jim's self-isolation proves a handicap for his establishing societal bonds, which provide a framework for a purposeful and moral life. Moreover, Marlow is aware of the fact that a man left to his own devices will never fully avoid self-delusion: "I didn't know how much of it he believed himself. I didn't know what he was playing up to-if he was playing up to anything at all-and I suspect he did not know either; for it is my belief that no man ever understands quite his own artful dodges to escape from the grim shadow of self-knowledge" (Conrad, 1996: 51). 


\section{THE SHADOW-LINE}

The free-flowing prose of the intensely personal narration in The Shadow-Line offers the story of an inexperienced but skilled seaman who, apparently without any logical reason, resigns from his post as mate on a steamship in the Eastern seas. By the end of the novella, the narrator-protagonist gains knowledge, insight and humility, feeling older, less conceited and more experienced. Having, crossed the shadowline between youth and maturity on his traumatic first command, he undergoes a moral initiation by ordeal, "a rite of passage into mature identity within the male world of the Merchant Navy” (Hampson, 1996: 141).

The narrator is recounting his story with the benefit of a hindsight, juxtaposing the youthful impetuosity and naïvety of the protagonist with the experienced voice of the mature narrator, which creates ironic undertones as well as invites general comment on the meaning of life, especially at the threshold of adulthood. At the outset of the novella, the young man claims that what prompted him to the rash act of stepping down from his position was a sense of the pointlessness of his actions, his own emotionality and, generally speaking, the painful epistemological void:

The past eighteen months, so full of new and varied experience, appeared a dreary, prosaic waste of days. I felt-how shall I express it? - that there was no truth to be got out of them.

What truth? I should have been hard put to explain. Probably, if pressed, I would have burst into tears simply. I was young enough for that. (Conrad, 2003: 6)

The days following his resignation are full of dejection for him, "the feeling of disillusionment, the fear of a world devoid of romantic or spiritual enchantment" (White, 1981: 121):

The whole thing strengthened in me that obscure feeling of life being but a waste of days, which, half-unconsciously, had driven me out of a comfortable berth, away from men I liked, to flee from the menace of emptiness... and to find inanity at first turn. [...]

A great discouragement fell on me. A spiritual drowsiness. Giles's voice was going on complacently; the very voice of the universal hollow conceit. And I was no longer angry with it. There was nothing original, nothing new, startling, informing to expect from the world; no opportunities to find out something about oneself, no wisdom to acquire, no fun to enjoy. Everything was stupid and overrated [...]. (Conrad, 2003: 19)

As noted by Cedric Watts, this reveals a Hamletian dimension to the narrator's mind (1993: 73). Indeed, what the young man experiences could be likened to a quest for revelation, or search for an ordering principle, as at the beginning, he "had never in [his] life felt more detached from all earthly goings on," and "Nothing in the way of abstraction could have equalled [his] deep detachment from the forms and colours of this world. It was, as it were, absolute" $(2003: 16,29)$.

Another issue the young man is initially oblivious to (and, consequently, sometimes arrogant about) are the limitations to one's romantic youthful dreams and one's idealised self-image. This theme is developed from the first pages of the novella as we witness the young seaman's decisions, behaviour and reflections. The abrupt and 
apparently unmotivated act of giving up his comfortable berth at the beginning of the novella could be interpreted as a typical act of youthful exaggeration due to rash judgment (Lothe, 1989: 120). Nevertheless, the analeptic hindsight in the formulation of the decision displays self-criticism, which enhances the narrator's reliability: "However, it's no use trying to put a gloss on what even at the time I myself half suspected to be a caprice" (Conrad, 2003: 4). His previous position seemed comfortable, promising, and meaningful, but, as he admits: "suddenly I left all this. I left in that, to us, inconsequential manner in which a bird flies away from a comfortable branch. [...] One day I was perfectly right and the next everything was gone-glamour, flavour, interest, contentment-everything" (Conrad, 2003: 4-5). Formerly, he demonstrates a "fretful self-preoccupation" (Watt, 2000: 155) and keeps pondering on his own capabilities which so far have not been given a chance to surface and develop, preferably in a dazzling manner.

Captain Giles, who is to become the protagonist's spiritual father, is intrigued by the narrator's apparent lack of an articulate reason for resigning and tries to elicit some answer or reflection from him. Giles asks about his motivations, and comments on the replies that he hears (sometimes also deluding himself), which at first bores: "I thought he was the most dull, unimaginative man I had ever met" [Conrad, 2003: 13]), but then greatly annoys the emotionally unstable young man: "I became angry all of a sudden; for you can understand how exasperating such [..]) question[s] [were] for a man who didn't know. I said to myself that I ought to shut up that moralist [...]" (2003: 12). When Giles recounts what Kent told him about regretting to have lost such a good first mate, he responds with an outburst of what he himself calls "childish irritation":

I flung away the paper I was still holding. I sat up, I slapped the table with my open palm. I wanted to know why he would keep harping on that, my absolutely private affair. It was exasperating, really I was about to turn away, withdrawing my privacy from his fatuous, objectless attempts to test what sort of stuff it was made of. (Conrad, 2003: 15, 16)

Indeed, it would seem that the young man is very sensitive, and attempts to protect himself against a rational examination of his irrationality, with aggression, which is a form of his defence mechanisms against gaining self-knowledge. Giles's line of argument "was irrelevant enough to be almost insulting. Insulting to one's intelligence, I mean. In that twilight region between youth and maturity, in which I had my being then, one is peculiarly sensitive to that kind of insult" (Conrad, 2003: 21-22). His self-preoccupation blinds him but eventually his complacency is disturbed, probably because he fears for the adequacy of the comments: "various thoughts occurred to me, such as: that Giles had been making fun of me, expecting some amusement at my expense; that I probably looked silly and gullible; that I knew very little of life" (Conrad, 2003: 20).

When, owing to Giles's help, the narrator secures his first command and wants to thank his mentor, he still has not overcome his youthful arrogance: "I extended my hand to him warmly and he seemed surprised, but did respond heartily enough in the end, with a faint smile of superior knowledge which cut my thanks short as if with 
a knife" (Conrad, 2003: 31). He does not appear to be mature enough as yet to be able to accept his own deficiencies, especially when they might be exposed by others. When Giles professes that "everybody in the world is a little mad," the narrator asks him whether there are no exceptions to this rule. The old captain responds:

"Why! Kent says that even of you."

"Does he?" I retorted, extremely embittered all at once against my former captain. "There's nothing of that in the written character from him which I've got in my pocket. Has he given you any instances of my lunacy?" (Conrad, 2003: 35)

The narrator's self-centredness and touchiness become notorious: he keeps suspecting others of contempt and mockery, as is the case with the captain who brought him to the ship that he was to take command of: "What was his tone? Mocking? Threatening? Or only indifferent? I could not tell. I suspected some malice in this unexpected manifestation of interest" (Conrad, 2003: 40). Such hypersensitivity, self-consciousness and continuous juxtaposition against others on the part of the protagonist may be related to his low self-esteem and a sense of inadequacy. This also seems to be true about the critical point of his first command, when he is overwhelmed by a plethora of threatening circumstances: "My first command. Now I understand that strange sense of insecurity in my past. I always suspected that I might be no good. And here is proof positive. I am shirking it. I am no good" (Conrad, 2003: 88). His oversensitive conscience in this critical situation may stem from a recognition of his own limitations, or the general incomprehensibility of things, but it could also be argued that it constitutes a form, or a new aspect, of the Captain's self-centredness. However, it is the crew's refusal to see things personally, and their persistence and solidarity, that divert him from the path of egocentrism.

When the psychological strain seems unbearable and the Captain is ready to give in to utter despair, it is the delicate suggestion from Ransome that prompts him to gather enough strength to face the adversities and the imminent tropical storm. The growing awareness of human interdependence in the face of one's own limitations, which never crossed his mind at the initial stages, when his self-absorption barred any concessions, marks another phase in his mental and moral growth.

Conrad seems to claim that one should pursue self-knowledge by striking a balance between a sense of community and a sense of loneliness. Work ethics, a sound perception of reality and human solidarity seem to be the remedies against the dangers of youthful emotionality and self-delusion in both novels. As indicated by Watt, "Conrad's thought had altered a good deal from Lord Jim: conceit and error and guilt are universal, but their consequences, it seems, are not irredeemable; we are all in the same boat with them, and with sickness and death, but if we seize our fleeting and partial opportunities, we can steer" (2000: 164). Hence, what each and every young man should learn in crossing the shadow-line is humility and the ability to control their emotions as well as accept their irrationality. A quest for self-knowledge involves shared awareness of human weaknesses and a need for solidarity in the face of the darkness of human nature and the world at large, even if the awareness and the knowledge gained are only those of human fallibility and lack of self-sufficiency. 


\section{WORKS CITED}

Berthoud, Jacques. Joseph Conrad: The Major Phase. Cambridge: Cambridge University Press, 1978.

Conrad, Joseph. (1900). Lord Jim. Ed. Thomas C. Moser. New York \& London: Norton, 1996. 2003.

. (1917). The Shadow-Line. Ed. Jeremy Hawthorn. Oxford: Oxford University Press,

Daleski, H.M. Joseph Conrad: The Way of Dispossession. London: Faber and Faber, 1977.

Hampson, Robert. "The Late Novels." The Cambridge Companion to Joseph Conrad. Ed. J.H. Stape. Cambridge: Cambridge University Press, 1996. 140-159.

Johnson, Bruce. "Conrad's Impressionism and Watt's 'Delayed Decoding." Conrad Revisited. Essays for the Eighties. Ed. Ross C. Murfin. Alabama: University of Alabama Press, 1985. 51-70.

Lothe, Jakob. Conrad's Narrative Method. Oxford: Clarendon Press, 1989.

Stape, J.H. "Lord Jim." The Cambridge Companion to Joseph Conrad. Ed. J.H. Stape. Cambridge: Cambridge University Press, 1996, pp. 63-80.

Tanner, Tony. Conrad: Lord Jim. London: Edward Arnold, 1963.

Watt, Ian. Conrad in the Nineteenth Century. London: Chatto and Windus, 1980. . Essays on Conrad. Cambridge: Cambridge University Press, 2000.

Watts, Cedric. A Preface to Conrad. Second Edition. London \& New York: Longman, 1993.

White, Allon. The Uses of Obscurity: The Fiction of Early Modernism. London, Boston \& Henley: Routledge and Kegan Paul, 1981. 